\title{
III Międzynarodowe Seminarium Naukowe „Aktualne problemy archiwistyki i zarządzania dokumentami”, Lublin 19 V 2018 r.
}

W Uniwersytecie Marii Curie-Skłodowskiej w Lublinie 19 V 2018 r. odbyło się III Międzynarodowe Seminarium Naukowe pt. „Aktualne problemy archiwistyki i zarządzania dokumentami”. Organizatorami spotkania były: Zakład Archiwistyki i Nauk Pomocniczych Historii Uniwersytetu Marii Curie-Skłodowskiej w Lublinie, Katedra Historiografii, Źródłoznawstwa i Archeologii Narodowego Uniwersytetu Charkowskiego, Instytut Pamięci Narodowej Oddział w Lublinie, Departament Historii Uniwersytet Naukowo-Badawczy Wyższa Szkoła Ekonomii w Sankt Petersburgu oraz Archiwum Państwowe w Lublinie. Seminarium zostało podzielone na cztery sekcje, $\mathrm{z}$ których dwie pierwsze odbyły się w Instytucie Historii UMCS, obrady sekcji trzeciej przeprowadzono w Instytucie Pamięci Narodowej Oddział w Lublinie, natomiast ostatnia miała miejsce w Archiwum Państwowym w Lublinie. W niniejszym sprawozdaniu z III Międzynarodowego Seminarium Naukowego pt. „Aktualne problemy archiwistyki i zarządzania dokumentami” została umieszczona relacja jedynie z części wystąpień.

Seminarium oficjalnie otworzył prof. dr hab. Krzysztof Skupieński, który w imieniu swoim oraz władz uniwersytetu powitał zgromadzonych gości oraz przedstawił główny cel spotkania wraz z jego harmonogramem. Moderatorami sekcji pierwszej byli dr Tomasz Matuszczak z Archiwum Państwowego w Piotrkowie Trybunalskim oraz dr Małgorzata Szabaciuk z Uniwersytetu Marii Curie-Skłodowskiej. Obrady sekcji otworzył referat wygłoszony przez Marcina Smoczyńskiego z Uniwersytetu Mikołaja Kopernika w Toruniu pt. „Wykaz akt i jego rola w sprawnym zarządzaniu dokumentacją”. Wykaz akt, który był przedmiotem wystąpienia, według prelegenta, obok instrukcji kancelaryjnej i instrukcji archiwalnej stanowi jeden z podstawowych normatywów regulujących prace kancelaryjne we współczesnych biurach oraz urzędach. W swoim przedstawieniu autor zwrócił uwagę na funkcję, jaką pełni obecnie w instytucjach wykaz akt. Celem wystąpienia było scharakteryzowanie wykazu akt, wskazanie jego najważniejszych cech, które mają najistotniejszy wpływ na właściwe zarządzanie dokumentacją w organizacji. 
Konrad Majchrzyk, student kierunku archiwistyka i nowoczesne zarządzanie zapisami informacyjnymi Uniwersytetu Marii Curie-Skłodowskiej, w wystąpieniu „AiNZZI - wrażenia, opinie, perspektywy” zaprezentował wyniki badania ankietowego, przeprowadzonego wśród studentów III roku kierunku AiNZZI. Celem przeprowadzonego badania było sprawdzenie opinii studentów o kierunku, który kończyli. Pytania w ankiecie były związane m.in. z oceną zajęć, wykładowców, praktyk. W większości respondenci wypowiadali się o kierunku studiów w sposób pozytywny, wśród wymienianych zalet znalazły się m.in. płatne praktyki, zajęcia prowadzone w sposób merytoryczny.

W wystąpieniu Karola Kaczora „Outsourcing w prowadzeniu elektronicznej dokumentacji medycznej. Podstawy prawne” została przeprowadzona analiza treści aktów prawnych pod kątem prowadzenia działalności outsourcingowej dla placówek medycznych, posiadających dokumentację medyczną w postaci elektronicznej. Podczas wystąpienia poruszono aktualną problematykę, związaną z wprowadzeniem RODO, analizowano także m.in. zapisy Ustawy z dn. 6 listopada 2008 r. o prawach pacjenta i Rzeczniku Praw Pacjenta związane $\mathrm{z}$ udostępnianiem, zabezpieczaniem oraz powierzeniem dokumentacji medycznej podmiotom zewnętrznym.

Konrad Gromadzki w referacie „Podstawy prawne rozwoju e-Government w Polsce" opisał akty prawne oraz strategie wprowadzone w Polsce, mające na celu rozwój e-administracji na terenie całego kraju. Prelegent przedstawił również początki procesów legislacyjnych w zakresie dostępu do informacji publicznej obywateli, a także utworzenia Biuletynu Informacji Publicznej. Poddał analizie główne założenia Uchwały Sejmu RP z dn. 14 lipca 2000 r. w sprawie budowania podstaw społeczeństwa informacyjnego w Polsce, m.in. zasadę powszechnego dostępu i wykorzystania Internetu, metodykę rozwoju systemów teleinformatycznych oraz plan rozwoju edukacji wśród obywateli państwa. Spośród najważniejszych strategii i planów wdrażania e-Government w Polsce zostały wyróżnione m.in. dokument Komitetu Badań Naukowych pt. Cele $i$ kierunki rozwoju społeczeństwa informacyjnego $w$ Polsce, strategia rozwoju spoleczeństwa informacyjnego na lata 2001-2006 ePolska, Program Zintegrowanej Informatyzacji Państwa z 2016 r., Strategia Sprawne Państwo 2020. Podsumowaniem dotychczasowych działań związanych z wdrożeniem e-administracji jest sprawozdanie opublikowane przez Najwyższą Izbę Kontroli. Najważniejsze uwagi po zakończonej kontroli dotyczyły niezapewnienia odpowiedniego systemu monitorującego postępy wdrażania strategii, brak współpracy między urzędami, koordynator strategii nie został wyposażony w narzędzia umożliwiające 
rzetelne wywiązywanie się z obowiązków koordynowania i nadzorowania realizacji strategii. NIK zwróciła również uwagę na kwestie finansowe wdrażania e-Government w Polsce oraz brak możliwości oszacowania kosztów całej strategii.

W wystąpieniu Kamili Biernat „Digitalizacja w archiwach państwowych” zaprezentowano możliwości dofinansowania digitalizacji materiałów archiwalnych w archiwach państwowych z programów operacyjnych oraz funduszy zagranicznych. Autorka referatu opisała założenia poszczególnych programów operacyjnych, wymieniła przykładowych beneficjentów, wskazała również główne kryteria oceny wniosków oraz możliwości wynikające z dofinansowań unijnych i zagranicznych. W pierwszej kolejności omówiono Program Operacyjny „Polska Cyfrowa”, którego głównym celem jest m.in. rozwój e-usług w sferze publicznej, szybki i nieograniczony dostęp obywateli do Internetu i informacji publicznej. Wśród wymienionych instytucji, które mogą korzystać ze wskazanego dofinansowania są archiwa państwowe. Środki pochodzące z programu mogą być przeznaczone na wprowadzenie zmian technologicznych, związanych z digitalizacją materiałów archiwalnych, ich publikacją na stronach internetowych oraz podniesienie kompetencji cyfrowych uczestników biorących udział w całym procesie. Jednym z głównych kryteriów oceny wniosków był wybór materiałów objętych digitalizacją, wcześniejsze przygotowanie konserwatorskie archiwaliów. Następnie omówiono Program Operacyjny Infrastruktura i Środowisko, zachowując tę samą formułę. Prelegentka przedstawiła programy krajowe, związane z dofinansowaniem digitalizacji, m.in. Wspieranie działań archiwalnych $w$ zakresie niepaństwowego zasobu archiwalnego 2016 - priorytet digitalizacja. Autorka wystąpienia zwróciła również uwagę na możliwość korzystania z dofinansowań zagranicznych, np. Funduszy Norweskich, których głównym celem jest ochrona dziedzictwa narodowego, w tym oczywiście materiałów archiwalnych, znajdujących się w zasobie archiwów państwowych.

Ostatnią część sekcji pierwszej poświęcono podsumowaniu dotychczasowych wystąpień oraz zainicjowaniu dyskusji wśród uczestników seminarium. Dyskusję rozpoczęto od nawiązania do referatu M. Smoczyńskiego, w którym przedstawiono koncepcję wskaźnika haseł kategorii A w stosunku do kategorii B w rzeczowym wykazie akt. Prelegent stwierdził, że głównym kryterium powinna być historyczność oraz wartość dokumentacji, mając jednocześnie na uwadze częste nadużywanie kategorii A, która w konsekwencji generuje zwiększenie kosztów dla organizacji. W czasie dyskusji pojawiły się również stwierdzenia, że hasła klasyfikacyjne mają zróżnicowaną częstotliwość użytkowania 
oraz ilość dokumentacji kryjącej się pod poszczególnymi pozycjami. Podczas dyskusji odniesiono się również do cech jednolitego rzeczowego wykazu akt, takich jak stabilność oraz elastyczność. Zwrócono uwagę na korzyści płynące z niezmienności JRWA, a jednocześnie konieczności jego dostosowywania do obowiązującego prawa, bądź zadań instytucji. W nawiązaniu do kolejnego referatu, autorstwa Katarzyny Miedwiediewy, omówiono pokrótce kwestie związane ze spuściznami znajdującymi się w zasobach archiwów ukraińskich. Podczas dyskusji ustalono, że dokumentacja ta stanowi niewielki procent całego zasobu archiwów ukraińskich, dodatkowym utrudnieniem przy tym rodzaju materiałów jest brak jasnych przepisów dotyczących ich opracowywania. W archiwach ukraińskich spuścizny stanowią głównie dokumentację wytworzoną przez byłych pracownikach naukowych, którzy mają świadomość wartości historycznej przekazywanych materiałów. Podczas prowadzonej debaty porównano kwestię udostępniania spuścizn w obydwu krajach. W przypadku państwowych archiwów polskich, niezależnie od formy ekspozycji, chętniej prezentowane są akta personalne, materiały związane $\mathrm{z}$ lokalnymi działaczami. W przypadku archiwów ukraińskich zwraca się przede wszystkim uwagę na gromadzenie oraz zabezpieczenie tych materiałów, a w dalszej kolejności skupia się na prezentacji, udostępnianiu.

W czasie dyskusji nawiązano również do kolejnego referatu, przedstawionego przez Konrada Majchrzyka, poruszającego zagadnienie opinii studentów na temat kierunku - archiwistyka. Doktor Tomasz Matuszak nawiązał w swojej wypowiedzi do własnych badań, przeprowadzonych wśród studentów archiwistyki w Filii Uniwersytetu Jana Kochanowskiego w Piotrkowie Trybunalskim, których wyniki w większości pokrywały się z zaprezentowanymi przez K. Majchrzyka. Oceniając użyte przez referenta narzędzie badawcze - ankietę - podczas przeprowadzonego badania wśród studentów archiwistyki Uniwersytetu Marii Curie-Skłodowskiej, wskazał brak możliwości samooceny studentów pod względem zaangażowania w zajęcia, w proces pozyskiwania wiedzy.

Dyskutanci odnieśli się również do kwestii statusu prawnego podpisu elektronicznego w Polsce. Poruszono m.in. wątek prawa europejskiego, które miało wpływ na uchylenie Ustawy z dn. 18 września 2001 r. o podpisie elektronicznym, wprowadzając jednocześnie Ustawę z dn. 5 września 2016 r. o usługach zaufania oraz identyfikacji elektronicznej.

W równoległym czasie rozpoczęły się obrady sekcji II, której moderatorami byli dr hab. Artur Górak z Uniwersytetu Marii Curie-Skłodowskiej oraz prof. dr hab. Janusz Łosowski, również z Uniwersytetu Marii Curie-Skłodow- 
skiej. Podczas drugiego panelu wystąpiło pięcioro zagranicznych prelegentów, poruszających zagadnienia związane $\mathrm{z}$ aktualnymi problemami archiwistyki i zarządzania dokumentacją w Rosji oraz na Ukrainie. Polskim akcentem wśród zagranicznych gości był doktorant Piotr Czyż, reprezentujący Uniwersytet Przyrodniczo-Humanistyczny w Siedlcach, który wygłosił referat pt. „Archiwalia muzealiami, muzealia archiwaliami? Rola archiwaliów w muzealnictwie na przykładzie wybranych muzeów". Prelegent oparł swoje wystąpienie na czterech instytucjach: Muzeum Zespołu Synagogalnego we Włodawie, Muzeum Józefa Ignacego Kraszewskiego w Romanowie, Muzeum Zamek w Łańcucie, Muzeum Polaków Ratujących Żydów podczas II Wojny Światowej im. Rodziny Ulmów w Markowej. W referacie ujęto obowiązujące normatywy prawne dotyczące zabezpieczenia, przechowywania, udostępniania oraz gromadzenia archiwaliów, a także muzealiów. W celu przybliżenia tematyki muzealiów oraz archiwaliów autor posłużył się reprezentacyjnymi obiektami, pochodzącymi ze wspomnianych instytucji.

Obrady sekcji III odbyły się w siedzibie Instytutu Pamięci Narodowej Oddział w Lublinie. Dyskusję i panel poprowadzili prof. Adrian Sielin (Wyższa Szkoła Ekonomii w Sankt Petersburgu), prof. Marcin Kruszyński (Instytut Pamięci Narodowej Oddział w Lublinie), dr hab. M. Konstankiewicz (Uniwersytet Marii Curie-Skłodowskiej w Lublinie). Referenci omawiali problemy związane z przemianami kulturowymi w kontekście zarządzania dokumentacją, poruszali kwestie dotyczące udostępniania materiałów archiwalnych oraz dostępu do informacji publicznej w kraju i za granicą.

W referacie pt. „Problemy udostępniania materiałów znajdujących się w zasobie IPN” Monika Gogół przedstawiła problematykę udostępniania zasobu Instytutu Pamięci Narodowej na podstawie Ustawy z dn. 18 grudnia 1998 r. o Instytucie Pamięci Narodowej - Komisji Ścigania Zbrodni przeciwko Narodowi Polskiemu oraz własne doświadczenie z pracy w IPN Oddział w Lublinie. W wystąpieniu zwrócono uwagę na głównych beneficjentów instytucji, wskazano możliwości ubiegania się o dostęp do materiałów zgromadzonych w archiwum oraz przedstawiono najczęściej występujące powody odmów udostępnienia materiałów w IPN. W referacie wspomniano również o systemie informacji archiwalnej, który udostępnił IPN w grudniu 2012 r. - Inwentarz archiwalny IPN - jest on niezbędnym narzędziem w procesie udostępniania materiałów archiwalnych użytkownikom archiwów.

Bartłomiej Wierzbowski w wystąpieniu „Biuletyn Informacji Publicznej jako narzędzie pracy archiwów bieżących” zaprezentował wyniki analizy biuletynów 
informacji publicznej archiwów bieżących, przeprowadzonej w okresie marzec maj 2017 r. na stronach 635 insty tucji, z których to 300 podmiotów posiadało archiwa zakładowe (ok. 47 proc.). Analizie treści Biuletynu Informacji Publicznej zostały poddane instytucje z całej Polski, takie jak: biblioteki, licea, muzea, sądy, prokuratury, szpitale, teatry, urzędy administracji rządowej oraz samorządowej, podmioty posiadające archiwa wyodrębnione. B. Wierzbowski na potrzeby badania skonstruował kwestionariusz, dzięki któremu mógł porównać informacje o archiwach bieżących, znajdujących się w Biuletynie Informacji Publicznej. Podmioty były analizowane pod względem występowania pięciu z założonych elementów. Pierwszy z nich dotyczył udostępniania informacji o funkcjonowaniu i zadaniach archiwów bieżących wybranych instytucji. Następny odnosił się do występowania w biuletynie opisu zasobu archiwów bieżących. Trzecie kryterium analizy dotyczyło zamieszczenia informacji na stronie biuletynu o podstawie prawnej, obowiązującej archiwa bieżące. Kolejnym elementem poddanym badaniu było umieszczenie informacji o możliwości ponownego wykorzystania informacji z sektora publicznego. Ostatnie pytanie w kwestionariuszu dotyczyło standardów technicznych, obowiązujących Biuletyn Informacji Publicznej.

Kaja Bachańska w swoim referacie pt. „Records management w kontekście dostępu informacji publicznej w Anglii" przedstawiła koncepcję records management, poddała analizie pojęcia archives, records, document na podstawie literatury anglosaskiej oraz m.in. Normy ISO 15489-1 z 2016 r. Prelegentka na podstawie aktu prawnego Freedom of Information Act 2000 przedstawiła również funkcjonowanie informacji publicznej w angielskich instytucjach, które mają zapewnić dostęp do informacji posiadanych przez władze, a członkowie społeczeństwa są uprawnieni do żądania tychże informacji od władz publicznych. Records management wprowadzone w instytucjach publicznych pozwala na sprawne zarządzanie informacją, bez względu na jej formę oraz udostępnianie jej w dowolnie wybranym momencie.

Ewelina Makoś w odczycie „Wprowadzenie elektronicznego postępowania upominawczego a przemiany kultury dokumentacyjnej" podkreślała znaczenie pojawienia się przepisów, wprowadzających do polskiego systemu prawnego nowe cywilne postępowanie upominawcze. EPU weszło $\mathrm{w}$ życie $\mathrm{z}$ dniem 1 I 2010 r. i zostało unormowane w Kodeksie postępowania cywilnego. Referentka opisała korzyści płynące z korzystania z elektronicznego postępowania upominawczego oraz wymagania, jakie musi spełnić pozew, aby został rozpatrzony. W wystąpieniu poruszono również kwestię pojęcia kultury dokumentacyjnej w kontekście dokonujących się przemian, przejścia z kultury tradycyjnej do kul- 
tury Internetu, m.in. za pomocą dokonującej się informatyzacji w postępowaniu sądowym.

Dyskusję sekcji III rozpoczął dr hab. A. Górak w związku z referatem K. Bachańskiej, odnosząc się do używanej terminologii w wystąpieniu referentki. Uczestnicy seminarium zwrócili uwagę na trudność w przetłumaczeniu na język polski terminów anglojęzycznych, w tym również record. Podczas dyskusji nawiązano do wystąpienia E. Makoś w związku ze wspomnianą definicją pojęcia kultury dokumentacyjnej oraz wymienieniem cech charakteryzujących nową oraz starą kulturę dokumentacyjną. Uczestnicy rozpatrywali rolę pozwanego w elektronicznym postępowaniu upominawczym.

Doktor T. Czarnota zwrócił się do M. Gogół z pytaniem o ocenę procedury udostępniania materiałów archiwalnych w Instytucie Pamięci Narodowej, biorąc pod uwagę specyfikę tej dokumentacji. W kwestii Instytutu Pamięci Narodowej głos zabrał prof. M. Kruszyński, który przedstawił wspomnianą instytucję jako miejsce otwarte dla użytkowników. Niemniej dokumenty znajdujące się w zasobie archiwum są wymagającym materiałem. Prof. M. Kruszyński przedstawił obecne zróżnicowane zadania IPN, nałożone przez ustawodawcę, związane m.in. z przyznawaniem dodatków dla osób działających w opozycji, redukcję emerytur w odniesieniu do byłych pracowników Służby Bezpieczeństwa. W związku z pracami przygotowującymi materiały archiwalne do udostępnienia, rozpatrzeniem wniosków oraz ze względu na wagę dokumentów w porównaniu z innymi rodzajami archiwów, nie ma możliwości uproszczenia procedury udostępniania archiwaliów. W następnej kolejności poruszono zagadnienia zaprezentowane w referacie B. Wierzbowskiego - zakwalifikowania archiwów wyodrębnionych jako subkategorię archiwów bieżących. Zwrócono także uwagę na wąski zakres wykorzystywania Biuletynu Informacji Publicznej przez archiwa bieżące, poszukując jednocześnie przyczyny tego zjawiska.

Sesję zakończyła wypowiedź prof. Marcina Kruszyńskiego, dziękującego referentom i słuchaczom za aktywny udział w dyskusji. Profesor zaprosił równocześnie do udziału w obradach sekcji IV, mających miejsce w Archiwum Państwowym w Lublinie. 